\title{
Chapter 1 \\ Plant Invasions in Protected Areas: \\ Outlining the Issues and Creating the Links
}

\author{
Llewellyn C. Foxcroft, David M. Richardson, Petr Pyšek, \\ and Piero Genovesi
}

\begin{abstract}
There are numerous excellent volumes on the topic of biological invasions, some of which deal with conservation-related issues to varying degrees. Almost 30 years since the last global assessment of alien plant invasions in protected areas during the SCOPE programme of the 1980s, the present book aims to provide a synthesis of the current state of knowledge of problems with invasive plants in protected areas. To set the scene we outline some of the major challenges facing the field of invasion biology. We discuss the extent and dimensions of problems that managers of protected areas deal with and what can be learnt from research and management interventions conducted in protected areas. A virtual tour through different regions of the world sheds light on the rapidly growing knowledge
\end{abstract}

\section{L.C. Foxcroft $(\square)$}

Conservation Services, South African National Parks, Private Bag X402, Skukuza 1350, South Africa

Centre for Invasion Biology, Department of Botany and Zoology,

Stellenbosch University, Private Bag X1, Stellenbosch 7602, South Africa

e-mail: Llewellyn.foxcroft@sanparks.org

D.M. Richardson

Centre for Invasion Biology, Department of Botany and Zoology,

Stellenbosch University, Private Bag X1, Stellenbosch 7602, South Africa

e-mail: rich@sun.ac.za

P. Pyšek

Department of Invasion Ecology, Institute of Botany, Academy of Sciences

of the Czech Republic, Průhonice CZ 252 43, Czech Republic

Department of Ecology, Faculty of Science, Charles University in Prague,

CZ 12844 Viničná 7, Prague 2, Czech Republic

e-mail: pysek@ibot.cas.cz

P. Genovesi

ISPRA, Institute for Environmental Protection and Research,

Via V. Brancati 48, I-00144 Rome, Italy

Chair IUCN SSC Invasive Species Specialist Group, Rome, Italy

e-mail: piero.genovesi@isprambiente.it 
base in different socio-geographical settings, and applies such insights to the problems that managers face. We hope that this book captures the core concerns and creates the critical links that will be needed if the growing impacts of alien plant invasions on protected areas are to be managed effectively. We also aim to promote the role of protected areas as leaders and catalysts of global action on invasive species, and key study areas for basic and applied invasion science.

Keywords Conservation • Impact • Invasive alien plants • Management • Nature reserve

\subsection{Protected Areas and Plant Invasions: History and Threats}

The target of conserving $10 \%$ of the world's ecological regions by 2010 was agreed to in 2004, at the seventh conference of the parties to the Convention on Biological Diversity (CBD 2004) and the CBD Strategic Plan for 2011-2020 raised this target to $17 \%$ (Aichi Target 11). A recent summary estimates that there are about 157,000 terrestrial and marine areas that enjoy some form of legal status as protected areas (PAs) worldwide. These PAs cover more than 24 million $\mathrm{km}^{2}$ (16 million $\mathrm{km}^{2}$ terrestrial; IUCN and UNEP-WCMC 2012; http://www.wdpa.org/Statistics. aspx). The number of PAs grew tenfold between 1962, when there were approximately 10,000, and 2003 (the 5th World Parks Congress in Durban) when there were about 100,000 (Mulongoy and Chape 2004). Terrestrial PAs grew from about $3.5 \%$ of the total land area in 1985 (Zimmerer et al. 2004), to $12.9 \%$ in 2009 (Jenkins and Joppa 2009).

Protected areas are the foundation of national and international conservation initiatives, and are mandated with conserving biodiversity (Dudley and Parish 2006). They are designed to protect representative portions of natural landscapes, ensure the persistence of biodiversity and key ecosystem processes, provide ecosystem goods and services, and in many cases to contribute significant economic benefits (Barrett and Barrett 1997; Margules and Pressey 2000). The role that PAs can play in mitigating the impacts of global climate change is also increasing in importance (Conroy et al. 2011).

Empirical evidence of the overall contribution of PAs in conserving biodiversity is scarce. Nonetheless, and despite some conflicting case studies (Bruner et al. 2001; Mora et al. 2009; Butchart et al. 2012), there is little doubt that, globally, PAs buffer representative areas of biodiversity from many threatening processes (Gaston et al. 2008). Protected areas are, however, becoming increasingly isolated in a matrix of human-altered landscapes (Koh and Gardner 2010). Habitat fragmentation not only reduces the total amount of habitat and subdivides it into fragments, but also introduces new forms of land use (Bennett and Saunders 2010). These landscapes, modified to varying extents for different uses, differ in their conservation value, and in their compatibility with adjacent PAs. Moreover, PAs are faced with a number of threats, displacing the species and eroding the 
systems underpinning the reasons for their establishment. Within PAs the growing global impacts of habitat loss, fragmentation and over-exploitation are often eliminated or can be managed to some extent. Many anthropogenic threats to biodiversity are, however, not removed through formal protection. This is especially true for smaller PAs and those with larger edge/total area ratios. Biological invasions, one of the most pressing environmental concerns globally, are one such threat.

The concept of setting aside tracts of land for different forms of protection dates back thousands of years (Mulongoy and Chape 2004), with many being declared as sacred sites (Dudley et al. 2005). For instance in northern India (2,000 years ago) and Indonesia (1,500 years ago) areas were protected for religious beliefs and as homes of the Gods. Estimates suggest that there may be as many sacred sites as PAs, many of which fall outside formally listed PAs (Dudley et al. 2005). Modern philosophies behind conservation or protected areas were related to maintaining vast tracts of wilderness (of which John Muir was a major advocate; Devall 1982), a landscape ethic (Leopold 1949), the protection of fragments of habitats that were rapidly disappearing, or to support sustainable utilization or wildlife conservation (Meine 2010). Wildlife conservation has often focused on the preservation of single species at high risk of extinction and/or protecting dwindling herds of typically charismatic large mammals. For example, the preservation of rare or endangered species, which are also often charismatic, played a major role in leading to the promulgation in 1905 of Kaziranga National Park in India to protect the one-horned rhinoceros (Rhinoceros unicornis; Dudley and Parish 2006).

The first national park proclaimed globally (and the first formal use of the term 'national park'), primarily for protection of its scenic beauty (Dudley and Stolton 2012), was Yellowstone National Park in the United States, in 1872. The proclamation of Yellowstone National Park was followed shortly thereafter by national parks in a number of countries. By 2008, the US National Park system covers $338,000 \mathrm{~km}^{2}$ of PAs, about $4 \%$ of the country, including representative landscapes of all of the nation's biomes and ecosystems (Baron et al. 2008). Designation and management of PAs as an approach to preventing degradation of particular parcels of land continued with a focus on species populations, maintaining states in equilibrium (notions of the 'balance of nature') or agriculturally based concepts such as carrying capacity (Rogers 2003). In the 1990s, conservation practices and management approaches had started moving away from protection of single species and their habitats, towards the consideration of interactive networks of species and an ecosystem-based approach (Ostfeld et al. 1997). Species-centric approaches often developed into crisis-orientated approaches, whereas focusing on largescale ecosystems and networks allows for the maintenance of the underlying requirements on which species depend (Fiedler et al. 1997; Ostfeld et al. 1997). There is also increasing acceptance by conservation agencies that systems are dynamic and heterogeneous, and that disturbance is both a driver and responder of system change (Pickett et al. 2003). Emerging concepts over the last decade include the growing understanding of the importance of ecosystem resilience for PAs (Wangchuk 2007; Baron et al. 2008; Hobbs et al. 2010) and that the interrelatedness of socio-ecological systems in the broader landscape are critical 
to long-term maintenance of PAs (Newton 2011). It is thus within this setting and new conservation paradigm that insights for invasion science may emerge.

In the USA, concern over alien species in the national parks was expressed by National Park Service scientists as early as in the 1930s (Houston and Schreiner 1995). Even earlier, however - shortly after the establishment of the Yosemite Valley state park in 1864, designated for public use and recreation - concerns about European weeds invading the park were raised (Randall 2011). In South Africa's Kruger National Park (established in 1898) the first official records of alien plants date to 1937, when six alien species were recorded during general botanical surveys (Foxcroft et al. 2003). In 1947 Bigalke, writing about the then National Parks Board of South Africa, published a strongly titled paper "The adulteration of the fauna and flora of our national parks". He stated that it should not be permissible to introduce animals and plants to a national park, and if the principle was not strictly adhered to the term 'national park' would have no meaning (Bigalke 1947). At a meeting of the American Association for the Advancement of Science (AAAS) in 1921, the council stated that it "...strongly opposes the introduction of non-native plants and animals into the national parks... and urges the National Park Service to prohibit all such introduction..." (Shelford 1926). Similar sentiments were expressed in Great Britain by the British Ecological Society in a report on nature conservation and nature reserves (British Ecological Society 1944).

Despite sentiments like these, some of the best-known examples of alien plant invasions come from PAs - and in some cases these are due to intentional introductions by park managers. For example, in Everglades NP, USA, Melaleuca quinquenervia (melaleuca) forms dense stands, replacing indigenous vegetation, altering habitats and fire regimes, and using large amounts of water (Schmitz et al. 1997). Schinus terebinthifolius (Brazilian pepper) has similar impacts, and has replaced Cladium jamaicense (saw grass) prairie and pineland with monospecific stands (Li and Norland 2001). Mimosa pigra (giant sensitive plant) is considered a major threat to Kakadu NP in Australia (Cowie and Werner 1993; Lonsdale 1993). Similarly, Morella faya (faya tree) in Hawaii Volcanoes NP has displaced the endemic Metrosideros polymorpha ('Ohi'a lehua) over large areas of protected land (Loope et al. 2014).

\subsection{The SCOPE Programme on Biological Invasions in the 1980s}

The last international research programme to focus specifically on invasive species in protected areas was a working group on invasions in nature reserves, initiated under the SCOPE (Scientific Committee on Problems of the Environment) programme on biological invasions in the 1980s (Wildlife Conservation and the Invasion of Nature Reserves by Introduced Species: a Global Perspective; Macdonald et al. 1989). The work on nature reserves culminated in a series of six 
papers published in the journal Biological Conservation, addressing invasions globally in nature reserves on islands (Brockie et al. 1988), on arid land (Loope et al. 1988), in tropical savannas and dry woodlands (Macdonald and Frame 1988), in Mediterranean-type climatic regions (Macdonald et al. 1988), and completed by a search for generalisations (Usher 1988). The central question posed by the working group on nature reserves was whether an undisturbed community could become invaded by alien species. The challenge, however, was to define such communities within which to work. It was felt that the best option would be in tracts of land that had been set aside to keep anthropogenic impacts on special features (e.g. wildlife and landscapes) to a minimum (Usher 1988). Using nature reserves as the sites most likely to accommodate these requirements, the working group aimed to (i) provide insights into differences between the extent to which natural and disturbed systems could become invaded; (ii) provide information on the consequences of invasions for indigenous species; and (iii) based on the outcomes, to provide management recommendations. The programme on nature reserves initially aimed to examine a larger list of biomes, but due to the lack of available information, work focussed on tropical and subtropical dry woodlands and savannas, Mediterranean-type shrublands and woodlands, arid lands, and oceanic islands. A total of 24 protected areas served as case studies.

Some findings from this SCOPE programme were that the nature and degree of invasions differ substantially between protected areas in different regions of the world. For example, it was suggested that nature reserves in arid regions of the tropics and sub-tropics have fewer invasive species (although notable exceptions were found); temperate regions in the northern hemisphere are relatively free of invasions, while reserves in the southern hemisphere were found to be severely impacted (Usher et al. 1988). All the nature reserves in the case studies included invasive vascular plants, comprising about $30 \%$ of the flora on island reserves and about $5 \%$ of all species in dry woodland and savanna (Usher 1988). Thus one of the most alarming generalisations of the programme at the time was the finding that all nature reserves contain invasive species and thus natural systems can indeed be invaded, some of them quite heavily. The authors also reported that invasions were found to impact both the structure and functioning of the ecosystems, and they recommended that priority should be given to species that threaten endemic species with extinction or those that have strong impacts at a landscape scale (Usher 1988). An important point was made that tourism poses dangers for invasions of reserves, as a positive correlation was detected between visitor numbers and numbers of introduced species (Usher 1988). This is obviously an increasingly concerning issue, as ecotourism is touted as a prime, low impact source of revenue in many parts of the world (see also Lonsdale 1999; Foxcroft et al. 2014).

Although the programme produced fundamental information on the invasibility of natural systems and the status of invasions across a number of regions globally, the six papers published in Biological Conservation have received less attention than deserved. Collectively the papers have been cited about 200 times, with half accruing to the synthesis paper (Usher 1988), Despite the growing intensity of research on biological invasions and the increasing focus on management issues (Richardson and 
Pyšek 2008; Pyšek and Richardson 2010), there has been no follow-up synthesis on the topic of plant invasions in PAs in the last two decades. The question of whether natural systems can be invaded by alien plants has been answered, but many other issues have arisen.

\subsection{Conservation and Policy Conventions}

The World Conservation Strategy of 1980, developed jointly by the IUCN, UNEP and WWF (1980), had three main objectives: the maintenance of essential life support systems, the maintenance of natural diversity and the sustained utilization of species and ecosystems. Interestingly, although alien and invasive species (at the time 'exotic' species) were mentioned in the strategy document at various points, the problem was not listed as one of the 14 priority issues, on par with, for example, soil erosion and its role in the degradation of catchment areas and watersheds. The effects of invasive alien species (IAS) were listed as one of the threats to wild species, impacting on competition for space or food, predation, habitat destruction or degradation, and the transmission of diseases and parasites. The species of concern, however, did not include any alien plants, citing only trout, bass, goats and rabbits. Freshwater systems and islands were indicated as particularly vulnerable.

It was largely through the SCOPE programme in the late 1980s that a larger, more detailed body of knowledge began accumulating. This provided the foundations on which improved policies could be formulated, leading to the current situation where issues related to biological invasions are included at all levels, from local to international, and in almost all biodiversity or conservation conventions, specialist groups and non-governmental organisations.

We indicate key issues raised by some of these conventions as examples. Highlighting these initiatives provides an indication of the acceptance and growing importance of biological invasions as an agent of global environmental change. In particular, they show the increasing concern of the problems to biodiversity and conservation.

\subsubsection{The Millennium Ecosystem Assessment}

The Millennium Ecosystem Assessment (2005) provided a global account of the status and trends of the greatest threats to biodiversity and has gained high level attention. The work highlighted biological invasions as the second most important global driver of biodiversity loss, and - together with climate change - the most difficult to reverse. The study stressed the absence of an adequate regulation for several pathways of introductions and considered the adoption of measures to control major pathways as a fundamental goal to address the IAS threats to biodiversity (Goal 6). 


\subsubsection{Convention on Biological Diversity (CBD)}

The adoption of the CBD by 101 countries in 1992 raised the political profile of IAS to an international level. The Convention (Article 8h) calls on contracting parties to "prevent the introduction of, control or eradicate those alien species which threaten ecosystems, habitats and species", with a number of key principles for addressing this threat being adopted (http://www.cbd.int/decision/cop/? $\mathrm{id}=7197$ ). The CBD has also given much attention to the threat of invasive species to PAs. For example, the joint CBD and UNEP-WCMC report on PAs and biodiversity (Mulongoy and Chape 2004) stated that “... widespread threat is that of alien invasive species which may be released, deliberately or accidentally, within a protected area, or may move in from surrounding areas". At the 10th CBD-COP (in Nagoya, 2010), the threat of IAS to PAs (http://www.cbd.int/decision/cop/? $\mathrm{id}=12297$ ) was again highlighted as an issue needing greater attention. Recognising the role of IAS as a key driver of biodiversity loss, the CBD invited the Parties to consider the role of IAS management as a cost-effective tool for the restoration and maintenance of protected areas and the ecosystem services they provide, and thus to include management of IAS in the action plans for implementation of the programme of work on PAs. At that occasion the CBD-COP adopted the Strategic Plan for Biodiversity 2011-2020, and 20 Aichi targets, including Target 9: "By 2020, invasive alien species and pathways are identified and prioritised, priority species are controlled or eradicated, and measures are in place to manage pathways to prevent their introduction and establishment".

\subsubsection{International Union for Conservation of Nature (IUCN)}

\subsubsection{Protected Areas Programme}

The 5th IUCN World Parks Congress in 2003 (Durban, South Africa) considered the need to manage IAS in PAs as an "emerging issue", stating that - "management of invasive alien species is a priority issue and must be mainstreamed into all aspects of protected area management". The Congress adopted a set of recommendations, including Recommendation I stating that pressures on PAs will increase as a result of global change, including invasions of alien species. The congress recognised and urged that "the wider audience of protected area managers, stakeholders and governments urgently need to be made aware of the serious implications for biodiversity, protected area conservation and livelihoods that result from lack of recognition of the IAS problem and failure to address it. Promoting awareness of solutions to the IAS problem and ensuring capacity to implement effective, ecosystem-based methods must be integrated into protected area management 
programmes. In addition to the consideration of benefits beyond boundaries, the impacts flowing into both marine and terrestrial PAs from external sources must be addressed" (https://cmsdata.iucn.org/downloads/emergingen.pdf).

\subsubsection{World Commission Protected Areas Programme}

The World Commission on Protected Areas (WCPA) is one of the five IUCN commissions, administered by IUCN's Global Programme on Protected Areas. It is a network of over 1,700 members, spanning 140 countries. The World Commission on Protected Areas aims to promote the establishment and effective management of a world-wide representative network of terrestrial and marine PAs as an integral contribution to IUCN's mission. To achieve this, WCPA supports planning of PAs and integrating them into all sectors, provides strategic advice to policy makers and strengthens capacity and investment in protected areas.

\subsubsection{IUCN SSC Invasive Species Specialist Group}

The Invasive Species Specialist Group (ISSG, http://www.issg.org/) is one of the five thematic specialist groups organised under the auspices of the Species Survival Commission (SSC) of the International Union for Conservation of Nature (IUCN). The ISSG, established in 1994, is a global network of scientific and policy experts on invasive species; it currently has about 200 core members from over 40 countries, and over 2,000 conservation practitioners and experts who contribute to its work. The three core activity areas of the ISSG are policy and technical advice, information exchange, and networking. The ISSG provides technical and scientific advice to, amongst others, the Convention on Biological Diversity, the Ramsar Convention, and the European Union. The ISSG promotes and facilitates the exchange of invasive species information, developing and managing the Global Invasive Species Database (GISD, http://www.issg.org/database/welcome), to provide information on the ecology of invasive species, their impacts and relevant management options. The GISD is cross-linked to the IUCN Red List of Threatened Species as well as the World Database on Protected Areas. The ISSG has worked with GISP to develop a scoping report on the threat of IAS to protected areas (De Poorter 2007). In 2012 a task force between IUCN SSC ISSG and the IUCN WCPA was established to produce guidelines for the management of IAS in PAs. In 2011 and 2012, IUCN and ISSG signed two Memoranda of Cooperation with the CBD Secretariat to provide support for the implementation of the Aichi targets in regard to the IAS issue. 


\subsubsection{Global Invasive Species Programme (GISP)}

In 1996, concern that globalization was having negative consequences on the environment led the United Nations and the Government of Norway to convene the first international meeting IAS that was held in Trondheim, Norway (Sandlund et al. 1998). Participants concluded that IAS had become one of the most significant threats to biodiversity worldwide and recommended that a global strategy and mechanism to address the problem needed to be created immediately. In 1997, The Global Invasive Species Programme (GISP) was established. Working primarily at international and regional levels, GISP aimed to build partnerships, provide guidance, develop a supportive environment and build capacity for national approaches towards the prevention and management of invasive species by pursuing three key objectives: (i) facilitating information exchange; (ii) supporting policy and governance; and (iii) promoting awareness among key public and private sector decision makers (http://www.gisp.org/about/mission.asp). A GISP report on IAS in PAs (De Poorter 2007) identified the following key impediments or challenges to implementing invasive species management in PAs: (i) lack of capacity for mainstreaming of invasive alien species management into protected area management overall; (ii) lack of capacity for invasive alien species management at site level; (iii) lack of awareness of invasive alien species impacts on protected areas, of the options for fighting back, and of the urgency of prevention and early detection; (iv) lack of consolidated information on invasive alien species issue in protected areas at national, international, and global levels; (v) lack of information, at site level, on what alien species are present, what risks they pose and how to manage them; (vi) lack of funding and other resources; (vii) high level impediment, for example legal, institutional or strategic issues; and (viii) clashes of interests.

Unfortunately, due to a lack of financial resources the GISP Secretariat closed in March 2011.

\subsubsection{Other International Conventions}

The Ramsar Convention on Wetlands has, at different occasions, stressed the specific threat of invasive alien species to wetlands, and at the 10th COP (held in Korea, 2008) adopted The Ramsar Strategic Plan (2009-2015; http://www.ramsar. org/cda/en/ramsar-documents-resol/main/ramsar/1-31-107_4000_0). This document highlights IAS among the "challenges that still require urgent attention in order to achieve wetland wise use under the Convention". Ramsar has encouraged parties to develop national inventories of IAS impacting wetlands. Similarly, the Convention on the Conservation of Migratory Species of Wild Animals (in Bonn, 1979) recognised the threat posed by invasive species to migratory species in several provisions, and has included the struggle against IAS in the Strategic Plan for 2006-2014. 


\subsection{Why This Book?}

Many books and syntheses have been written on biological invasions, covering all dimensions of the discipline (see for example, Simberloff 2004; Cadotte et al. 2006; Nentwig 2007; Davis 2009; Richardson 2011). Much work has also been done on PAs since the SCOPE programme on nature reserves (Fig. 1.1), but the focus of the work, and areas assessed, varies considerably in different parts of the world. However, even with the progress in the field and the increasing number of publications, there has been no synthesis on the topic.

We set three main aims for this book:

(i) To determine the status of knowledge on plant invasions in protected areas and synthesise these insights;

(ii) To integrate this with current models and theories of plant invasion ecology;

(iii) To determine key knowledge areas for informing the development of successful management strategies.

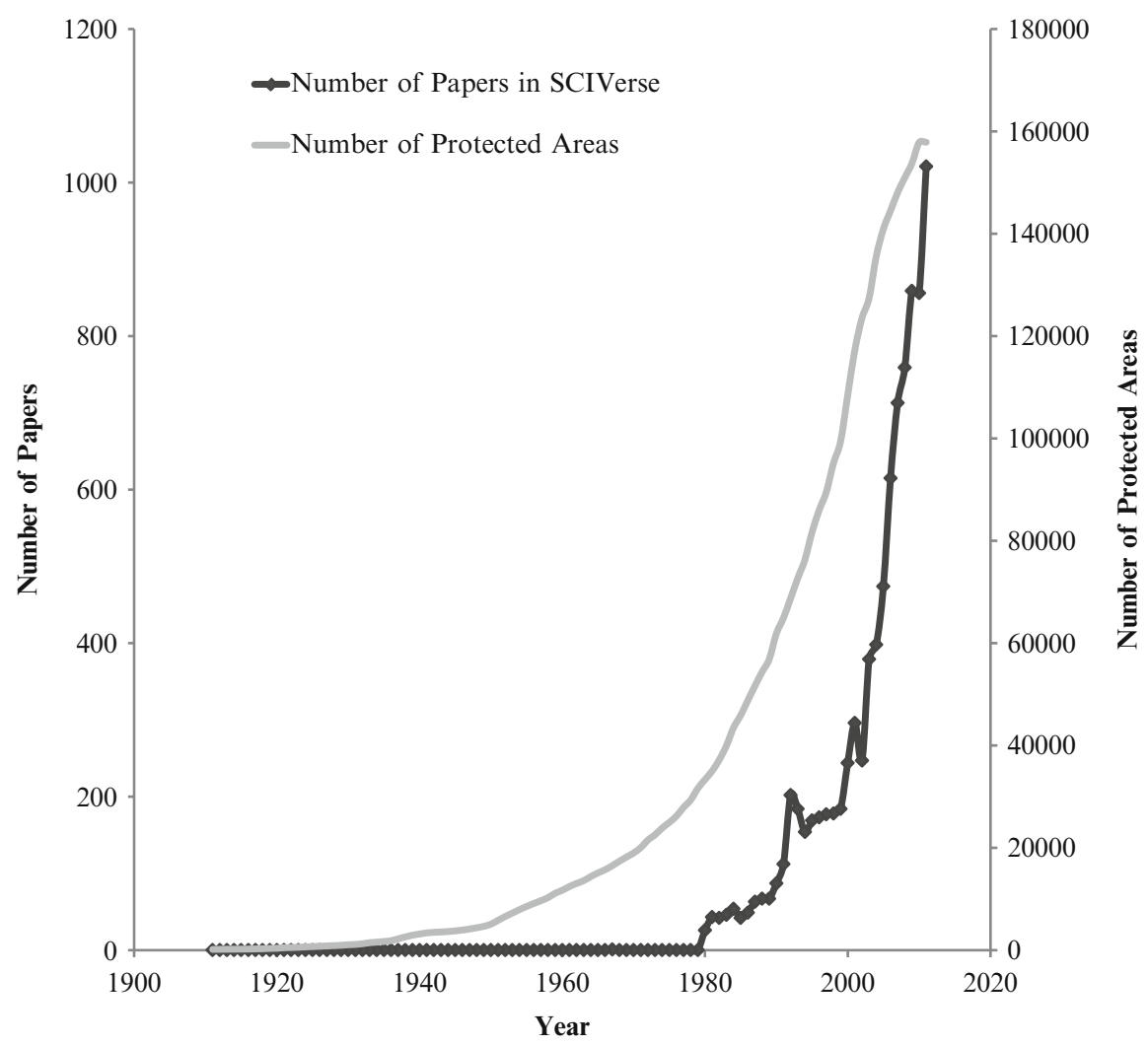

Fig. 1.1 Cumulative increase in numbers of publications referring to studies on biological invasions in protected areas [from SCIVerse science direct; search: alien OR non-native OR invasive OR biological invasion OR plant invasions AND protected area OR nature reserve OR heritage site OR national park OR wilderness OR marine park], and in number of protected areas (Data from IUCN and UNEP-WCMC 2012) 


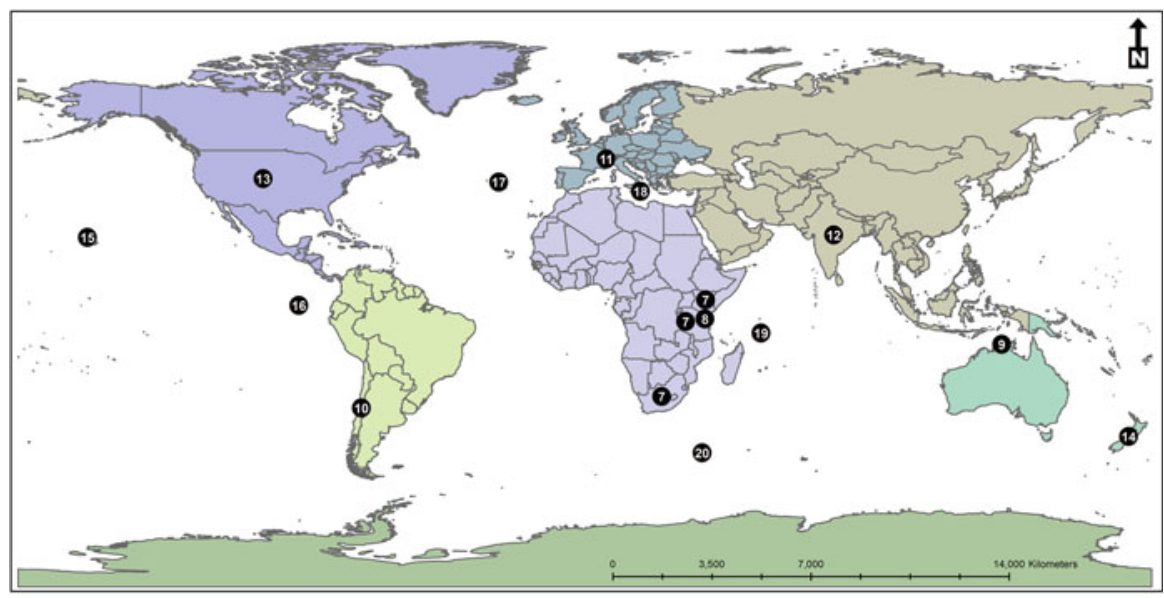

Fig. 1.2 Global map of regions discussed in the book. Numbers refer to the specific chapters

To achieve these objectives we aimed to cover a wide range of regions, as well as a variety of types of PAs and problems. We requested authors to specifically explore a number of issues pertinent to PAs. The book comprises three parts. The first section examines a number of general questions in invasion ecology; these are cross-cutting issues relevant to all regions. Here the authors discuss whether protected areas provide unique opportunities for gaining insights into these focal topics, and how work in PAs could provide further advances in the field. We also asked how PAs could be better used as model systems for future research. These topics include the role of PAs for developing an improved understanding of plant invasions and succession in natural systems, impacts of plant invasions, human dimensions of invasions, restoration, and large scale monitoring. The second part consists of case studies of plant invasions in PAs from 14 regions around the world (Fig. 1.2), including specific reference to about 135 protected areas. The case studies aim to capture experiences and to synthesise what has been done on invasive plants in PAs of different kinds and different sizes, in various environmental settings, and what has been learned from the research and management experiences in these areas. Case studies also explored the specific context of the systems and their unique attributes, and whether these aspects can provide natural laboratories for examining questions that cannot be studied in other regions. Specific attributes may include the modes and pathways of introduction and dispersal, impacts on biodiversity (whether species diversity, habitat structure or ecosystem function), the role of natural disturbance regimes (and whether these hold clues for understanding anthropogenic disturbance) and the usefulness of working in a range of sizes and types of PAs.

We also believe that these aims are crucial for providing knowledge that can contribute to meeting the Aichi target 9, and for ensuring full implementation of the provisions of Aichi target 11, which calls for effective management of the world's PAs. Moreover, effective management of IAPs is embodied in Aichi target 12, as being essential for reducing the rate of biodiversity loss. 


\subsection{Science in Protected Areas: Opportunities for the Future}

The IUCN suggests that the main uses of protected areas are scientific research, wilderness protection, preservation of species and genetic diversity, maintenance of environmental services, protection of specific natural and cultural features, tourism and recreation, education, sustainable resource use and maintenance of cultural and traditional attributes (Mulongoy and Chape 2004). Invasive alien plants threaten, can impact on and respond to all these major attributes. As more reliance is being placed on PAs for ensuring the persistence of global biodiversity and related services, insight into how invasion processes progress and how systems function, or are likely to function, in an invaded state is essential for understanding the potential of PAs to fulfil their mandate. A number of other properties enhance the appeal of potential research sites: PAs cover a range of habitats and sizes, allowing for investigations at small plot scales, to large catchment type experiments. Many PAs are receiving increasing management attention, which can be factored into developing further understanding, and the outcomes can in return be implemented in management approaches directly, allowing for adaptation and further learning. With the increasing attention to PAs in general, a management body can protect or maintain research sites in the medium- to longer-term. This has already resulted in a number of PAs becoming focal points for research across a range of disciplines, which may allow for improved interaction and integration (for example, du Toit et al. 2003; Sinclair et al. 2008).

\subsection{Management of Plant Invasions: The Future Roll of Protected Areas}

Protected areas are crucial for protecting the global diversity and ecosystem services we all rely upon for our very existence. However, only evidence-based policy and management, developed through rigorous science, will allow us to respond appropriately to the growing environmental crisis. We believe that PAs can and should play a major role in combating invasions, not only by improving the efficacy of IAS management within their territories, but also raising awareness at all levels, improving the capacity of practitioners to deal with invaders, implementing site-based prevention efforts, enforcing early detection and rapid response frameworks, and catalysing action also beyond the park boundaries (Genovesi and Monaco 2014). Protected areas can thus be reservoirs of biodiversity, but also sentinels of invasions as well as of other emerging threats to biodiversity, champions of best practises, and catalysts of action also at a broader scale than that of the PAs. 


\subsection{Terminology}

As with many fields in the conservation and ecological sciences, a plethora of terminology has arisen for describing issues relating to biological invasions. Much of the lexicon of invasions is heavily contested. For the purposes of this book we have adopted a generalised lexicon.

In defining invasions by alien plants we adopt the terminology associated with the introduced-naturalization-invasion continuum as elucidated by Richardson et al. (2011) and the proposed unified framework for biological invasions as set out by Blackburn et al. (2011). These frameworks provide the basis for the objective classification of the status of introduced species and for the related discussion of associated processes (see also Richardson and Pyšek 2012).

Many different terms and categories are used to define 'protected areas' in different parts of the world, reflecting the national objectives, societal needs and approaches to management. The IUCN definition of protected areas is: "A clearly defined geographical space, recognised, dedicated and managed, through legal or other effective means, to achieve the long-term conservation of nature with associated ecosystem services and cultural values" (Dudley 2008). The IUCN classifies PAs as one of six categories: Ia: strict nature reserve/wilderness protection area; Ib: wilderness area; II: national park; III: natural monument; IV: habitat/species management area; V: protected landscape/seascape; and VI: managed resource protected area. Similarly, but more simply, the term 'protected area' may be used to designate any area specifically designed or formally proclaimed for the protection of biodiversity, landscapes (natural or cultural) and processes therein. Different chapters and case studies refer to specific types of protected areas such as IUCN WDPA categories, nature reserves, heritage sites, Ramsar wetland sites, marine reserves or parks, wilderness areas and others.

Acknowledgments We thank Dan Simberloff for his support for this book. LCF thanks South African National Parks for supporting work on this book and for general support. LCF and DMR thank the Centre for Invasion Biology, the National Research Foundation (South Africa) and Stellenbosch University for support. PP was supported by long-term research development project no. RVO 67985939 (Academy of Sciences of the Czech Republic), institutional resources of Ministry of Education, Youth and Sports of the Czech Republic, and acknowledges the support by Praemium Academiae award from the Academy of Sciences of the Czech Republic. We thank Zuzana Sixtová for technical assistance with editing.

\section{References}

Baron JS, Allen CD, Fleishman E et al (2008) National parks. In: Adaptation options for climate-sensitive ecosystems and resources. The U.S. Climate Change Science Program, Washington, DC, p 35

Barrett NE, Barrett JP (1997) Reserve design and the new conservation theory. In: Pickett STA, Ostfeld RS, Shachak M et al (eds) The ecological basis of conservation. Heterogeneity, ecosystems and biodiversity. Chapman and Hall, New York, pp 236-251 
Bennett AF, Saunders DA (2010) Habitat fragmentation and landscape change. In: Sodhi NS, Ehrlich PR (eds) Conservation biology for all. Oxford University Press, Oxford, pp 88-104

Bigalke R (1947) The adulteration of the fauna and flora of our national parks. S Afr J Sci 43:221-225

Blackburn TM, Pyšek P, Bacher S et al (2011) A proposed unified framework for biological invasions. Trends Ecol Evol 26:333-339

British Ecological Society (1944) Nature conservation and nature reserves. J Ecol 1:45-82

Brockie RE, Loope LL, Usher MB et al (1988) Biological invasions of island nature reserves. Biol Conserv 44:9-36

Bruner AG, Gullison RE, Rice RE et al (2001) Effectiveness of parks in protecting tropical biodiversity. Science 291:125-129

Butchart SHM, Scharlemann JPW, Evans MI et al (2012) Protecting important sites for biodiversity contributes to meeting global conservation targets. PLoS One 7:e32529

Cadotte MW, McMahon SM, Fukami T (2006) Conceptual ecology and invasion biology: reciprocal approaches to nature. Springer, Berlin

CBD (2004) Convention of biological diversity, CoP 7 decision VII/30. Strategic plan: future evaluation of progress. Goal 1 - promote the conservation of the biological diversity of ecosystems, habitats and biomes; Target 1.1. http://www.cbd.int/decision/cop/?id=7767. Accessed 17 Feb 2013

Conroy MJ, Runge MC, Nichols JD et al (2011) Conservation in the face of climate change: the roles of alternative models, monitoring, and adaptation in confronting and reducing uncertainty. Biol Conserv 144:1204-1213

Cowie ID, Werner PA (1993) Alien plant species invasive in Kakadu National Park, Tropical Northern Australia. Biol Conserv 63:127-135

Davis MA (2009) Invasion biology. Oxford University Press, Oxford

De Poorter M (2007) Invasive alien species and protected areas: a scoping report. Part 1. Scoping the scale and nature of invasive alien species threats to protected areas, impediments to invasive alien species management and means to address those impediments. Global Invasive Species Programme, Invasive Species Specialist Group. http://www.issg.org/gisp_publica tions_reports.htm

Devall B (1982) John Muir as deep ecologist. Environ Rev 6:63-86

du Toit JT, Rogers KH, Biggs HC (eds) (2003) The Kruger experience. Ecology and management of savanna heterogeneity. Island Press, Washington

Dudley N (ed) (2008) Guidelines for applying protected area management categories. IUCN, Gland. http://data.iucn.org/dbtw-wpd/edocs/PAPS-016.pdf

Dudley N, Parish J (2006) Closing the gap. Creating ecologically representative protected area systems: a guide to conducting the gap assessments of protected area systems for the convention on biological diversity. Secretariat of the Convention on Biological Diversity, Montreal

Dudley N, Stolton S (eds) (2012) Protected landscapes and wild biodiversity, vol 3. Values of protected landscapes and seascapes. Protected Landscapes Specialist Group of IUCN's World Commission on Protected Areas. International Union for Conservation of Nature, Gland

Dudley N, Higgins-Zogib L, Mansourian SM (2005) Beyond belief: linking faiths and protected areas to support biodiversity conservation. Arguments for Protection. WWF, Equilibrium and Alliance of Religions and Conservation (ARC). World Wide Fund for Nature, Gland

Fiedler PL, White PS, Leidy RA (1997) A paradigm shift in ecology and its implications for conservation. In: Pickett STA, Ostfeld RS, Shachak M et al (eds) The ecological basis of conservation. Heterogeneity, ecosystems, and biodiversity. Chapman and Hall, New York, pp 83-92

Foxcroft LC, Henderson L, Nichols GR et al (2003) A revised list of alien plants for the Kruger National Park. Koedoe 46:21-44

Foxcroft LC, Pyšek P, Richardson et al (2014) Chapter 2: Impacts of alien plant invasions in protected areas. In: Foxcroft LC, Pyšek P, Richardson DM, Genovesi P (eds) Plant invasions in protected areas: patterns, problems and challenges. Springer, Dordrecht, pp 19-41 
Gaston KJ, Jackson SF, Cantú-Salazar L et al (2008) The ecological performance of protected areas. Ann Rev Ecol Evol Syst 39:93-113

Genovesi P, Monaco A (2014) Chapter 22: Guidelines for addressing invasive species in protected areas. In: Foxcroft LC, Pyšek P, Richardson DM, Genovesi P (eds) Plant invasions in protected areas: patterns, problems and challenges. Springer, Dordrecht, pp 487-506

Hobbs RJ, Cole DN, Yung L et al (2010) Guiding concepts for park and wilderness stewardship in an era of global environmental change. Front Ecol Environ 8:483-490

Houston DB, Schreiner EG (1995) Alien species in national parks: drawing lines in space and time. Conserv Biol 9:204-209

IUCN and UNEP-WCMC (2012) The World Database on Protected Areas (WDPA): February 2012 [On-line]. UNEP-WCMC, Cambridge. http://www.protectedplanet.net/. Accessed 21 Oct 2012

IUCN-UNEP-WWF (1980) World conservation strategy: living resource conservation for sustainable development. International Union for Conservation of Nature and Natural Resources, United Nations Environment Programme, World Wildlife Fund. doi:10.2305/IUCN.CH.1980.9.en

Jenkins CN, Joppa L (2009) Expansion of the global terrestrial protected area system. Biol Conserv 142:2166-2174

Koh LP, Gardner TA (2010) Conservation in human-modified landscapes. In: Sodhi NS, Ehrlich PR (eds) Conservation biology for all. Oxford University Press, Oxford, pp 236-258

Leopold A (1949) A sand county almanac and sketches here and there. Oxford University Press, New York

Li Y, Norland M (2001) The role of soil fertility in invasion of Brazilian pepper (Schinus terebinthifolius) in Everglades National Park, Florida. Soil Sci 166:400-405

Lonsdale WM (1993) Rates of spread of an invading species: Mimosa pigra in Northern Australia. J Ecol 81:513-521

Lonsdale WM (1999) Global patterns of plant invasions and the concept of invasibility. Ecology $80: 1522-1536$

Loope LL, Sanchez PG, Tarr PW et al (1988) Biological invasions of arid land nature reserves. Biol Conserv 44:95-118

Loope LL, Meyer J-Y, Hughes RF (2014) Chapter 15: Plant invasions in protected areas of tropical Pacific Islands, with special reference to Hawaii. In: Foxcroft LC, Pyšek P, Richardson DM, Genovesi P (eds) Plant invasions in protected areas: patterns, problems and challenges. Springer, Dordrecht, pp 313-348

Macdonald IAW, Frame GW (1988) The invasion of introduced species into nature reserves in tropical savannas and dry woodlands. Biol Conserv 44:67-93

Macdonald IAW, Graber DM, DeBenedetti S et al (1988) Introduced species in nature reserves in Mediterranean-type climatic regions of the world. Biol Conserv 44:37-66

Macdonald IAW, Loope LL, Usher MB et al (1989) Wildlife conservation and the invasion of nature reserves by introduced species: a global perspective. In: Drake J, Mooney HA, Di Castri F (eds) Biological invasions: a global perspective. Wiley, Chichester, pp 215-255

Margules CR, Pressey RL (2000) Systematic conservation planning. Nature 405:243-253

Meine C (2010) Conservation biology: past and present. In: Sodhi NS, Ehrlich PR (eds) Conservation biology for all. Oxford University Press, Oxford, pp 7-22

Millennium Ecosystem Assessment (2005) Ecosystems and human well-being: biodiversity synthesis. World Resources Institute, Washington, DC

Mora C, Myers RA, Coll M et al (2009) Management effectiveness of the world's marine fisheries. PLoS Biol 7:e1000131

Mulongoy KJ, Chape SP (eds) (2004) Protected areas and biodiversity: an overview of key issues. CBD Secretariat/UNEP-WCMC, Montreal/Cambridge

Nentwig W (ed) (2007) Biological invasions. Springer, Berlin

Newton AC (2011) Social-ecological resilience and biodiversity conservation in a 900-year-old protected area. Ecol Soc 16:13 
Ostfeld RS, Pickett STA, Shachak M et al (1997) Defining the scientific issues. In: Pickett STA, Ostfeld RS, Shachak M (eds) The ecological basis of conservation. Heterogeneity, ecosystems, and biodiversity. Chapman and Hall, New York, pp 3-10

Pickett STA, Cadenasso ML, Benning TL (2003) Biotic and abiotic variability as key determinants of savanna heterogeneity at multiple spatiotemporal scales. In: du Toit JT, Rogers KH, Biggs HC (eds) The Kruger experience: ecology and management of savanna heterogeneity. Island Press, Washington, DC, pp 22-40

Pyšek P, Richardson DM (2010) Invasive species, environmental change and management, and health. Ann Rev Environ Res 35:25-55

Randall JM (2011) Protected areas. In: Simberloff D, Rejmánek M (eds) Encyclopaedia of biological invasions. University of California Press, Berkley/Los Angeles, pp 563-567

Richardson DM (ed) (2011) Fifty years of invasion ecology: the legacy of Charles Elton. WileyBlackwell, Oxford

Richardson DM, Pyšek P (2008) Fifty years of invasion ecology: the legacy of Charles Elton. Divers Distrib 14:161-168

Richardson DM, Pyšek P (2012) Naturalization of introduced plants: ecological drivers of biogeographical patterns. New Phytol 196:383-396

Richardson DM, Pyšek P, Carlton JT (2011) A compendium of essential concepts and terminology in invasion ecology. In: Richardson DM (ed) Fifty years of invasion ecology: the legacy of Charles Elton. Wiley-Blackwell, Oxford, pp 409-420

Rogers KH (2003) Adopting a heterogeneity paradigm: implications for management of protected savannas. In: du Toit JT, Rogers KH, Biggs HC (eds) The Kruger experience: ecology and management of savanna heterogeneity. Island Press, Washington, DC, pp 41-58

Sandlund OT, Schei PJ, Åslaug V (eds) (1998) Invasive species and biodiversity management. Kluwer Academic Publishers, Dordrecht

Schmitz DC, Simberloff D, Hofstetter RH et al (1997) The ecological impact of nonindigenous plants. In: Simberloff D, Schmitz D, Brown T (eds) Strangers in paradise. Impact and management on nonindigenous species in Florida. Island Press, Washington, DC, pp 39-62

Shelford VE (1926) Naturalist's guide to the Americas. Williams and Wilkins, Baltimore

Simberloff D (2004) A rising tide of species and literature: review of some recent books on biological invasions. BioScience 54:247-254

Sinclair ARE, Packer C, Mduma SAR et al (eds) (2008) Serengeti III: human impacts on ecosystem dynamics. University of Chicago Press, Chicago

Usher MB (1988) Biological invasions of nature reserves: a search for generalizations. Biol Conserv 44:119-135

Usher MB, Kruger FJ, Macdonald IAW et al (1988) The ecology of biological invasions into nature reserves: an introduction. Biol Conserv 44:1-8

Wangchuk S (2007) Maintaining ecological resilience by linking protected areas through biological corridors in Bhutan. Trop Ecol 48:176-187

Zimmerer KS, Galt RE, Buck MV (2004) Globalization and multi-spatial trends in the coverage of protected-area conservation (1980-2000). Ambio 33:520-529 